\title{
Integrated chronostratigraphy of the Pliocene-Pleistocene interval and its relation to the regional stratigraphical stages in the southern North Sea region
}

\author{
G. Kuhlmann ${ }^{1,2,{ }^{*}}$, C.G. Langereis ${ }^{1,{ }^{* *}}$, D. Munsterman ${ }^{2}$, R.-J. van Leeuwen ${ }^{2}$, R. Verreussel $^{2}$, \\ J.E. Meulenkamp ${ }^{1} \&$ Th.E. Wong ${ }^{1,2}$ \\ 1 Faculty of Earth Sciences, Utrecht University, Budapestlaan 4, 3584 CD Utrecht, the Netherlands. \\ 2 TNO Built Environment and Geosciences - National Geological Survey of the Netherlands, Princetonlaan 6, 3584 CB Utrecht, the Netherlands. \\ * Present address: GeoForschungsZentrum Potsdam, Telegrafenberg, 14473 Potsdam, Germany. \\ ** Corresponding author. Email: langer@geo.uu.nl
}

Manuscript received: June 2005; accepted: January 2006

\begin{abstract}
Time-stratigraphic interpretations of Late Pliocene to Early Pleistocene sediments from onshore locations and from marginal marine settings of the North Sea Basin often refer to the subdivision of the Dutch and British 'Quaternary' regional stratigraphic stages. Since age control for these stages and their stage boundaries are based on relative dating methods, in this study pollen, dinoflagellate cysts and foraminiferal assemblages were investigated to correlate the regional stratigraphic stages independently to the global chronostratigraphy and the paleomagnetic timescale. The data were obtained from eight boreholes located in the depocentre setting of the Late Pliocene North Sea Basin comprising a $1000 \mathrm{~m}$ thick sedimentary succession. The British Gedgravian and Waltonian stages, the Dutch Reuverian to Brunssumian as well as published foraminiferal zones (NSB 14, FB and the lower part of the FA2 zone) fall within the Zanclean and Piacenzian. The lower boundaries of the Pre-Ludhamian and Pretiglian stages and of the NSB 14 to 15 zones are close to the paleomagnetic Gauss-Matuyama boundary. The Pre-Ludhamian, Ludhamian, Thurnian and the Pretiglian, Tiglian A and Tiglian B stages presumably cover the marine isotope stages 103 to 95 . It is proposed that the Ludhamian, Thurnian and the Tiglian A were short lasting, warm, periods during which sea level highstand facilitated sedimentary deposition at the marginal areas of the North Sea Basin. The lower boundary of the paleomagnetic Olduvai subchron is situated in the Tiglian C1-4b stage while the TC4C stage is found within the Olduvai subchron. Foraminiferal NSB 15 and NSB 16 zone as well as the upper part of the FA2 and FA1 zone fall within the Gelasian and cover the Matuyama chron as well as the lower part of the Olduvai subchron. Comparison with formerly dated North Sea sediments shows a good agreement between foraminiferal zonations on a broader scale but significant differences in absolute ages occur. Strontium isotope values indicate approximately 1 Ma younger ages as expected from our chronostratigraphic model. This discrepancy is explained by the dominance of freshwater from river discharge contributing high amounts of eroded material to the basin, leading to an increase of the ${ }^{87} \mathrm{Sr} /{ }^{86} \mathrm{Sr}$ ratio in the shelf-sea water.
\end{abstract}

Keywords: North Sea, dinoflagellate cysts, foraminifers, pollen, Pliocene, Pleistocene, regional stratigraphy, chronostratigraphy

\section{Introduction}

A comprehensive chronostratigraphy for the Miocene and Pliocene in the North Sea Basin is difficult to establish because of the progradational character of the sediments. During these times, the North Sea Basin was part of the North West European Basin and reached over the present day off-shore and onshore parts of the Netherlands, Germany and Denmark. It was confined by landmasses except towards the north where it opened into the Atlantic (Bijlsma, 1981; Glennie, 1990; Ziegler, 1990). The central North Sea Basin was filled with more than 3.000 metres of siliciclastic sediments (Ziegler, 1990) (Fig. 1) during the Cenozoic and half of these sediments were deposited during the Neogene. Towards the south, the London-Brabant Massif separated the North Sea Basin from the Atlantic, although at some times during the Pliocene a connection through the English Channel might have existed (Funnel, 1996). This thick interval offers the possibility for high-resolution 


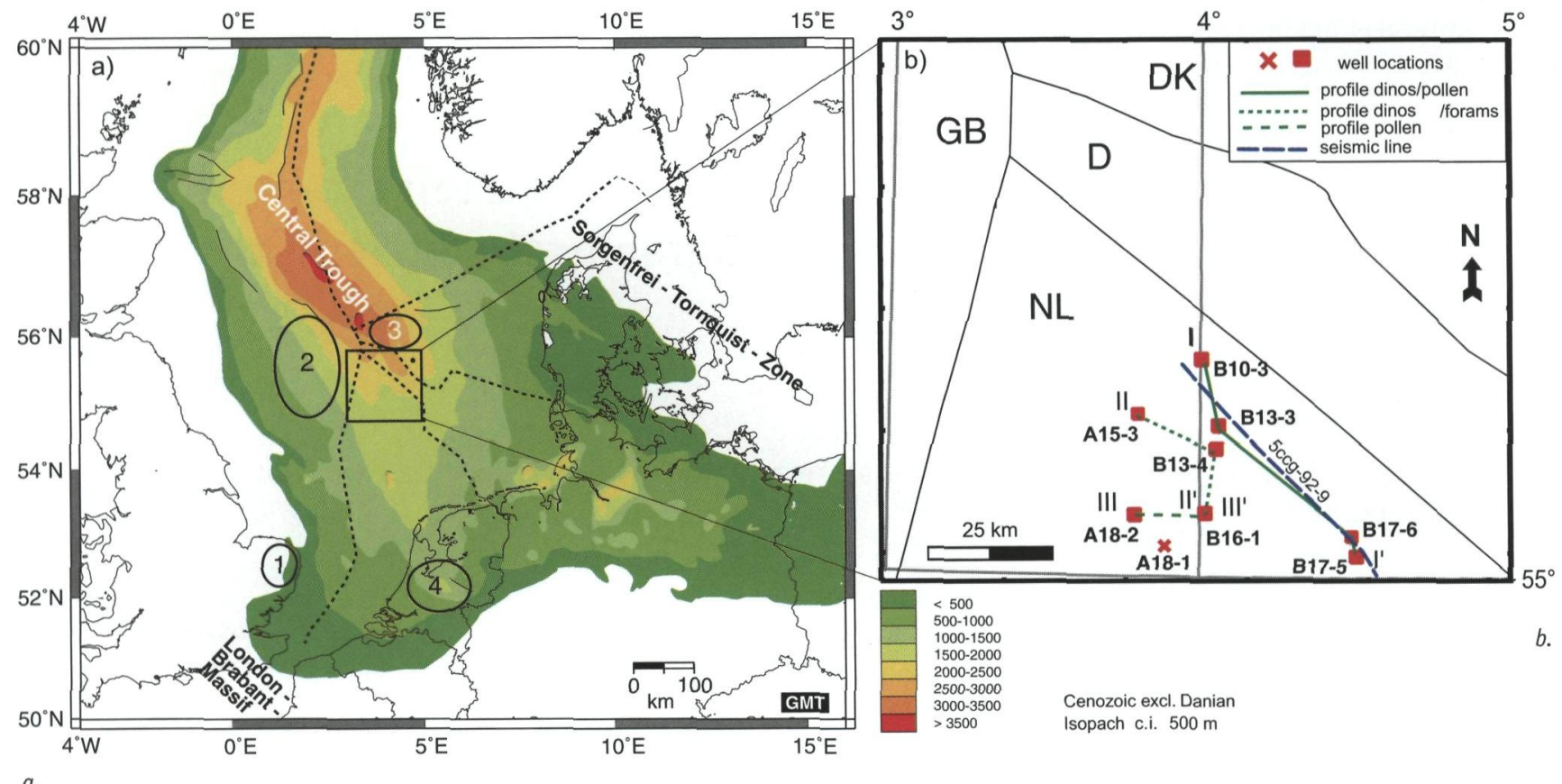

Fig. 1. a. Location map of the North Sea Basin with indicated thickness for the Cenozoic sediments (excl. Danian) after Ziegler (1990) and Huuse (2002). The square indicates the study area and the circles the study areas on which the regional biostratigraphic studies are done. $1=$ dinocyst studies (SE England), 2,3 = foraminifer studies (central southern North Sea), 4 = pollen studies (the Netherlands); b. Boreholes used in this study with three well-log profiles (I-I', II-II', III-III') taken for biostratigraphic correlation.

stratigraphic studies. While in the eastern part of the North Sea (e.g. Danish and German sectors) Miocene sediments are more complete, Pliocene sediments reach the greatest thickness more towards the west and north (e.g. Dutch and Norwegian sectors) of the basin. Because of the marginal marine setting of the surrounding areas, sedimentary sections from the presentday onshore regions are often incomplete. Nevertheless, prevailing stratigraphic concepts for the Pliocene to Pleistocene succession are based on these fragmentary onshore records. In the offshore region, age control is mainly based on lowresolution biostratigraphic data from ditch cuttings taken in exploration wells. These datasets from on- and offshore data have not yet been integrated into one standard. Furthermore, control on absolute ages is scarce and the resolution of the available information is still not sufficient for detailed studies of the Pliocene - Pleistocene interval of the North Sea region.

Comprehensive work on the regional stratigraphy for the Northwest European Tertiary Basin has been compiled by Vinken (1988). Gibbard et al. (1991) focussed more on regional interpretations and correlations of the Pliocene and Pleistocene time interval. Until now chronostratigraphical interpretations of Late Pliocene to Early Pleistocene sediments widely refer to the subdivision of the Dutch and British 'Quaternary' (Fig. 2). Therein, the Pliocene - Pleistocene boundary was placed at the base of the Pretiglian in the Netherlands subdivision. There is still much controversy on the position of this boundary (Zagwijn, 1992; Berggren et al., 1995a and 1995b; Mauz, 1998). Since the internationally accepted definition of the Global
Standard Stratotype Section and Point (GSSP) for the PlioPleistocene boundary is located just below the top of the Olduvai subchron (chron C2n) at 1.81 Ma (Lourens et al., 1996), Vrica section, Italy (Aguirre \& Pasini, 1985), we follow this latter definition in this study. However, the former definition is marked in Figure 2 to avoid confusion with available literature.

The Dutch subdivision, widely used as a regional standard (Zagwijn, 1985), dates back to Van der Vlerk \& Florschütz (1950) and Zagwijn (1957). It is based on the interpretation of pollen assemblages from the SE Netherlands in terms of climate change. The British stages are also primarily based on pollen studies (West, 1961; Beck et al., 1972). Both schemes were further developed with respect to faunal and floral data and correlated by Gibbard et al. (1991) (Fig. 2) to the Netherlands scheme. However, the subdivision of this regional biostratigraphy did not evolve from the study of long continuous records, but is a synthetic, conceptual framework based on a large number of small outcrops and borehole sections. Paleomagnetic data from the Netherlands onshore region (Van Montfrans, 1971; Zagwijn, 1974; Kasse, 1996; Van den Berg \& Van Hoof, 2001) placed the base of the Pretiglian close to the Gauss-Matuyama boundary (Van Adrichem Boogaert \& Kouwe, 1997) and the base of the Tiglian C5 close the top of the Olduvai (Hallam \& Maher, 1994). Through these points the regional stratigraphic scheme can be correlated to the global chronostratigraphy, although correlations of paleomagnetic boundaries in between these two chronozones are still uncertain and reveal numerous discrepancies and uncertainties (Fig. 2). 


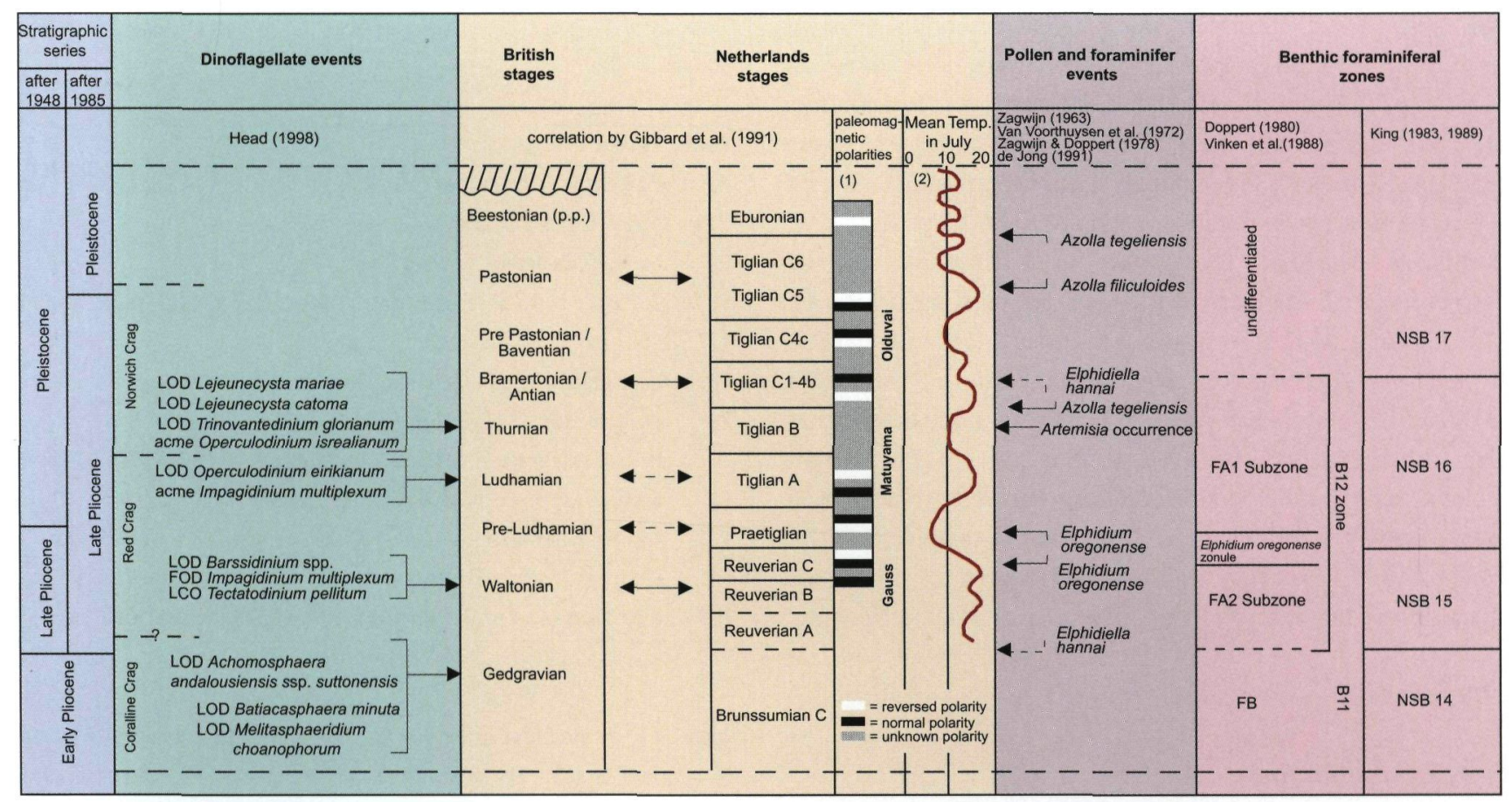

Fig. 2. Compilation of the different regional stratigraphic zonations and stages with their most important dinocyst, pollen and foraminifer events. British and Netherlands regional biostratigraphic schemes for the Pliocene-Pleistocene with the most important dinocysts, pollen and foraminifer events and their correlation by Gibbard et al. (1991). The stratigraphic series for the Pliocene and Pleistocene are indicated as defined after the Geological Congress, London, 1948 (Oakley, 1949) and their actual definition after 1985 (Aguirre \& Pasini, 1985). The paleomagnetic polarities (1) are compiled after Boenigk et al. (1979), Hallam \& Maher (1994), Kasse (1996), Urban (1978) and Van Montfrans (1971). The climate curve (2) has been redrawn from Zagwijn \& Doppert (1978). Foraminiferal subzones FA1, FA2 and FB are taken from Doppert (1980), the B11/B12 zone from Vinken et al. (1988) and NSB zones from King $(1983,1989)$.

Connected with the regional stratigraphic scheme of Zagwijn (1985) (Fig. 2), a zonation of benthic foraminiferal assemblages has been established by Doppert (1980). Other foraminiferal zonations have been compiled for the North Sea Cenozoic by King (1983, 1989), Gradstein \& Backström (1996) and Eidvin et al. (1999). For the Pliocene and Pleistocene, these zonations are mainly based on benthic foraminifers. For benthic species facies control must be regarded as an important factor, and has to be taken into account when using benthic foraminiferal zonations. Planktonic species are generally very scarce in the Upper Cenozoic sediments of the North Sea Basin but there are some datums that can be linked to magnetostratigraphically dated sections in the North Atlantic (Weaver \& Clement, 1986; Weaver, 1987).

Dinoflagellate cysts (further shortly named dinocysts) are an important part of the plankton in nutrient-enriched waters like marginal seas and oceanic fronts and provide potentially useful stratigraphical datums (Harland, 1992; Cameron et al., 1984) in the North Sea Basin. Detailed information about the British stratigraphical stages (Fig. 2) is given by the dinocyst distribution of the onshore Plio-Pleistocene of South East England by Head (1998a). Through studies from the North Atlantic (Harland, 1979; Mudie, 1989; de Vernal et al., 1992; Versteegh, 1995; Matthiessen \& Brenner, 1996; Poulsen et al.,
1996; Smelror, 1999) the dinocyst record of the southern North Sea Basin can be compared with the global standard record.

An integrated chronostratigraphy, based on eight boreholes of the northernmost Dutch offshore sector has been established by Kuhlmann (2004) for the North Sea Pliocene. The biostratigraphic data sets (i.e. dinocysts, foraminifers and pollen) have been tied to the most recent GPTS (Geomagnetic Polarity Time Scale) through an independently derived paleomagnetic record. In this study, we use the biostratigraphical events of Kuhlmann (2004) for detailed correlation between the boreholes and for an interpretation of the regional stratigraphical stages. Since neither the exact ages for most of the regional stratigraphical stages nor their duration are known, the chronostratigraphic framework of Kuhlmann (2004) is taken to connect the interpreted regional stratigraphic stages derived from this study to the global chronostratigraphic context. Additionally, strontium isotopes were measured to test another method for independent time control.

\section{Material and Methods}

The material used for this study was derived from eight exploration wells (Fig. 1b). Most of the samples consist of sidewall cores and cores; ditch cuttings were only used when unavoidable. 
The sample distribution over the different boreholes is shown in figures 4 to 6 . Biostratigraphic analyses were done on dinocysts (103 core samples, 70 ditch cuttings), foraminifers (122 core samples, 33 ditch cuttings) and pollen (233 core samples). For detailed sample preparation and analyses reference is made to Kuhlmann (2004). The biostratigraphic events as described there were used to constrain the correlation of the gamma-ray (GR) logs between the boreholes. Through interpretation of the gamma-ray logs correlatable logunits were defined. The overall compilation of the events led to an integrated framework of biostratigraphic events that were subsequently interpreted with respect to the current regional stratigraphic models. Additionally, strontium isotope measurements were performed on three samples of one borehole (B13-3) after standard procedures at the mass spectroscopy laboratory of the University of Bergen, Norway.

\section{Results}

\section{Correlation diagrams}

The biostratigraphic interpretation resulted in twelve consistent pollen events from five wells, thirteen dinocyst events from six wells and sixteen foraminiferal events from three wells). The events are based on First 0ccurrence Datums (FOD), First Common Occurrences (FCO), peak/acme occurrences, Last Common Occurrences ( $\mathrm{LCO}$ ) and Last Occurrence Datums (LOD). In Tables 1 to 3 the events are listed by name and will be discussed with regard to the correlating gamma-ray logunits. The correlations are presented in one north-south well log profile (I-I', Fig. 1b) in which all three fossil groups have been investigated (wells B10-3, B13-3 and B17-5/B17-6). The other profiles include the wells A18-2 and B16-1 (profile II-II', Fig. 1b) in which pollen have been analysed, and wells A15-3, B16-1 and B13-4 (profile III-III', Fig. 1b) in which

Table 1. Dinoflagellate cyst events with the codes used in the well-log correlation panels.

\begin{tabular}{ll}
\hline Code & Dinoflagellate cyst events \\
\hline D13 & LOD Amiculosphaera umbracula \\
D12 & LOD acme (2) Filisphaera/Habibacysta/Bitectatodinium \\
D11 & F0D acme (2) Filisphaera/Habibacysta/Bitectatodinium \\
D10 & LC0 Operculodinium israelianum \\
D9 & peak abundance (2) Operculodinium israelianum \\
D8 & LOD Impagidinium multiplexum \\
D7 & peak abundance (1) Operculodinium israelianum \\
D6 & LC0 Impagidinium multiplexum \\
D5 & peak abundance Impagidinium multiplexum \\
D4 & LOD acme (1) Filisphaera/Habibacysta/Bitectatodinium \\
D3 & FOD acme (1) Filisphaera/Habibacysta/Bitectatodinium \\
D2 & LOD Barssidinium spp. \\
D1 & LOD Melitasphaeridium choanophorum \\
\hline
\end{tabular}

Table 2. Pollen events with the codes used in the well-log correlation panels.

\begin{tabular}{ll}
\hline Code & Pollen events \\
\hline P11 & F0D Azolla filiculoides \\
P10 & LC0 Ericales $(\geqslant 20 \%)$ \\
P9 & base Pinus acme $(\geqslant 40 \%)$ \\
P8 & Top fourth (4) Picea peakinterval \\
P7 & F0D Azolla tegeliensis \\
P6 & base third (3) peakinterval Picea $(\geqslant 10 \%)+$ Osmunda acme \\
P5 & Base second (2) Ericales acme $(\geqslant 20 \%)$ \\
P4a & Peak occurrence Artemisia + Pediastrum peak \\
P4 & second (2) Picea peak + Osmunda acme \\
P3 & Top first (1) Ericales acme $(<10 \%)$ \\
P2 & First (1) Picea peak $(\geqslant 10 \%)$ \\
P1 & Base first (1) Ericales acme $(>10 \%)+$ F0D Pediastrum \\
\hline
\end{tabular}

Table 3. Foraminifer events with the codes used in the well-log correlation panels. The bold letters indicate species taken as time consistent markers.

\begin{tabular}{ll}
\hline Code & Foraminifer events \\
\hline F12 & apparent LOD foraminifers \\
F11 & LCO Elphidiella hannai \\
F10 & LOD Bulimina aculeata \\
F10a & LCO Bulimina aculeata \\
F9 & F0D Haynesina orbiculare \\
F8 & LCO Cassidulina \\
F7 & LCO keeled Cassidulina \\
F6 & F0D FA1 assemblage (with B. frigida) \\
F14 & LCO Melonis affinis \\
F13 & L0D Monspeliensina pseudotepida \\
F5 & LCO Neogloboquadrina atlantica (s) \\
F4 & Base second (2) Bulimina aculeata acme \\
F3a & FCO Elphidiella hannai \\
F3 & F0D Elphidiella hannai \\
F2 & Top first (1) Bulimina aculeata acme \\
F1 & L0D Asterigerna staeschei \\
\hline
\end{tabular}

\section{LOD Last occurrence \\ LCO Last common occurrence \\ FCO First common occurrence \\ FOD First occurrence}

dinocysts were studied. Sr-isotope measurements have been done on Elphidium excavatum on three samples of well B10-3 (for sample depths in the composite section see Fig. 6).

The seismic profile in Figure 3 shows the sedimentary setting for the wells located on profile line I-I'. The profile displays the seismic expression of logunit 10 and the exceptional location of B17-5 on a saltdome. More details on seismic interpretation are given in Kuhlmann (2004). Since the gamma-ray 


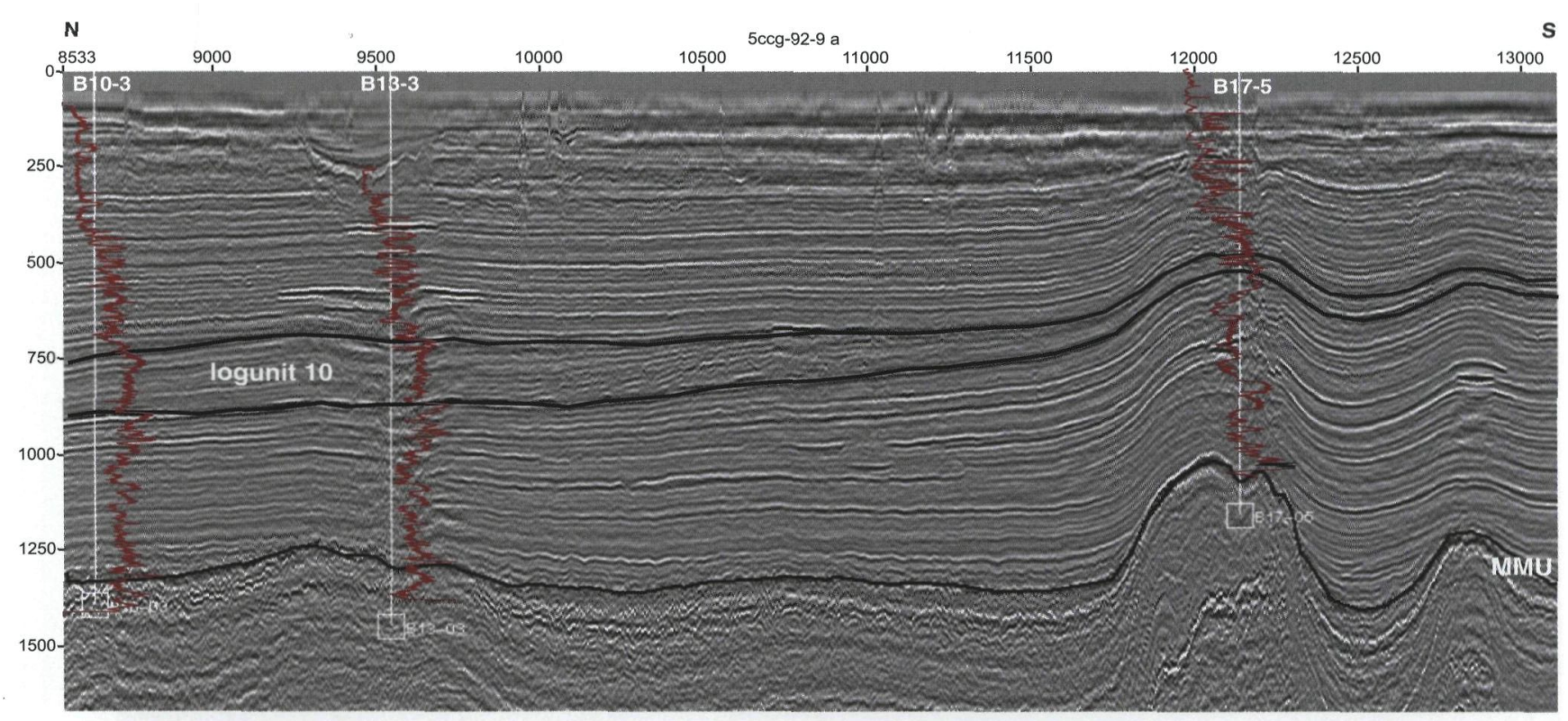

Fig. 3. Seismic profile (5ccg-92-9), comprising three of the investigated boreholes (B10-3, B13-3, B17-5) with their GR logs.

response records sediment attributes (i.e. the radioactivity of uranium, thorium, and potassium), correlation of the signal variations might depend on facies and could therefore represent diachronous features. However, since the biostratigraphic data showed synchrony between logstratigraphical units derived from the interpreted gamma-ray record and from the most consistent biostratigraphical events, we assumed that the logunit boundaries represent time equivalent horizons.

\section{Pollen}

The stratigraphic positions of the twelve pollen events are shown in figures $4 \mathrm{a}$ and $4 \mathrm{~b}$. The interval between the P1 and P3 event (first Ericales acme) appears consistently in all wells between the middle/base of logunit 6 and the top of logunit 9 . Only in well B17-5 this interval is found in what we consider to be logunits $7 / 8$ to 10 . These units are probably condensed or eroded and will be discussed in more detail in connection with the foraminiferal results. As the log interpretation in well B17-5 is not as straightforward as in the other wells, the P3 datum in this well is not very certain. The P2 event (first Picea peak) at the base of logunit 9 is only evident in well A18-2. The $\mathrm{P} 4$ event (second Picea peak and Osmunda acme) is found in two wells (B10-3 and B13-3) at the base of logunit 10. The P4a event (peak occurrence of Artemisia and Pediastrum) occurs in all wells at the broad GR peak of logunit 10, on behalf of this event this logunit has been assigned in well B17-5. The P5 event (base of the second Ericales acme), from logunits 11 in wells A18-2 and B16-1 and from logunit 12 in wells B10-3, B13-3 and B17-5, introduces an interval with enhanced but variable Ericales content that ends with the P10 event (LCO Ericales) which is recognised in logunit 18. In well B16-1 this event occurs slightly earlier, i.e. in logunit 16. The
P6 event (base third Picea interval) occurs in wells B13-3 and A18-2, in logunit 13 while it appears in logunit 15 in wells B10-3 and B17-5. The P7 event (FOD Azolla tegeliensis) event has been detected in well B13-3, logunit 14, and B17-5, logunit 17. The P8 event (top of the fourth Picea interval) occurs in all wells (except of B16-1 where no such an event is found) in logunit 17. The P9 event (base Pinus acme) is consistently found (wells B10-3, B13-3 and A18-2) within logunit 18. The P11 event (F0D Azolla filiculoides) is found at the top or above logunit 18 in wells B13-3 and A18-2.

\section{Dinoflagellate cysts}

The stratigraphical position of the thirteen dinocyst events are shown in figures $5 \mathrm{a}$ and 5b. The D1 event (LOD Melitasphaeridium choanophorum) occurs in wells B10-3 and A15-3 in logunit 1, and in B13-3 and B17-6 higher, in logunit 3. The D2 event (LOD Barssidinium spp.) occurs consistently at the top of logunit 5 , except for well B13-3, where this species has not been determined. The interval between the D3 and D4 event (encompassing the first Filisphaera/Habibacysta/Bitectatodinium acme) is found between logunit 6 and the base of logunit 9. In one borehole (B13-3) the acme starts earlier, logunit 4, and in another (B13-4) it ends earlier, in logunit 4. The peak abundance of Impagidinium multiplexum (D5) is seen consistently at the top of logunit 9 with the LCO of this species (D6) near the top of logunit 9 in wells B13-3, B17-6, B16-1, B13-4; in well B10-3 the D6 event coincides with the D5 event. The LOD of Impagidinium multiplexum (D8) occurs at the base (B10-3), in the lower part (B13-3, A15-3) and the upper part of logunit 10 (B17-6, B16-1). Two peak occurrences of Operculodinium israelianum (D7 and D9) appear at the base and at the top of logunit 10; only in well B13-4 the D9 event is slightly higher. 
The LCO of Operculodinium israelianum (D10) is seen in logunit 12 (B13-4), logunit 13 (B16-1, A15-3) and logunit 15 (B13-3). A second Filisphaera/Habibacysta/Bitectatodinium acme between the events D11 and D12 is mostly found within logunits 16 and 17; only in well B10-3 this acme starts already in logunit 12.

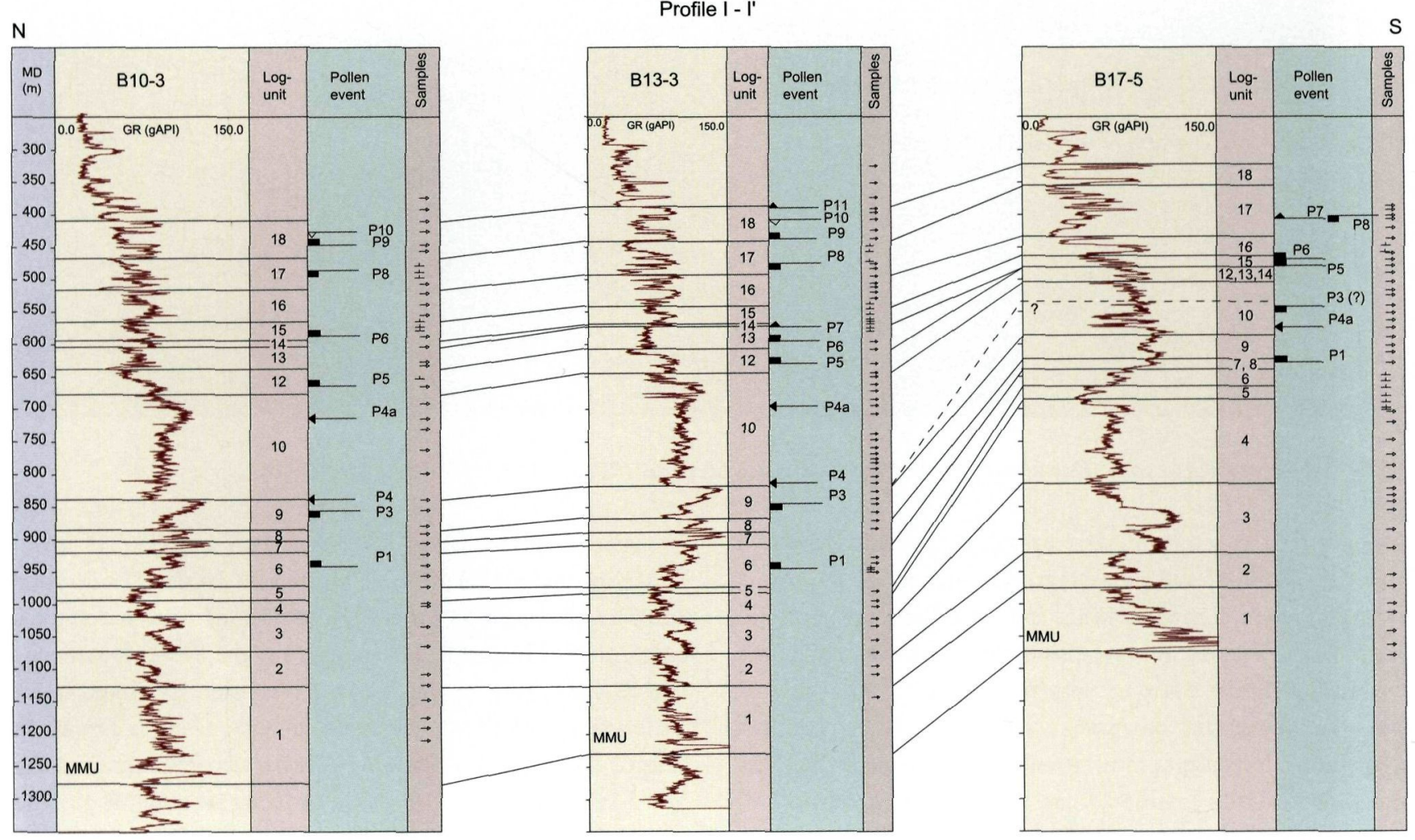

a.

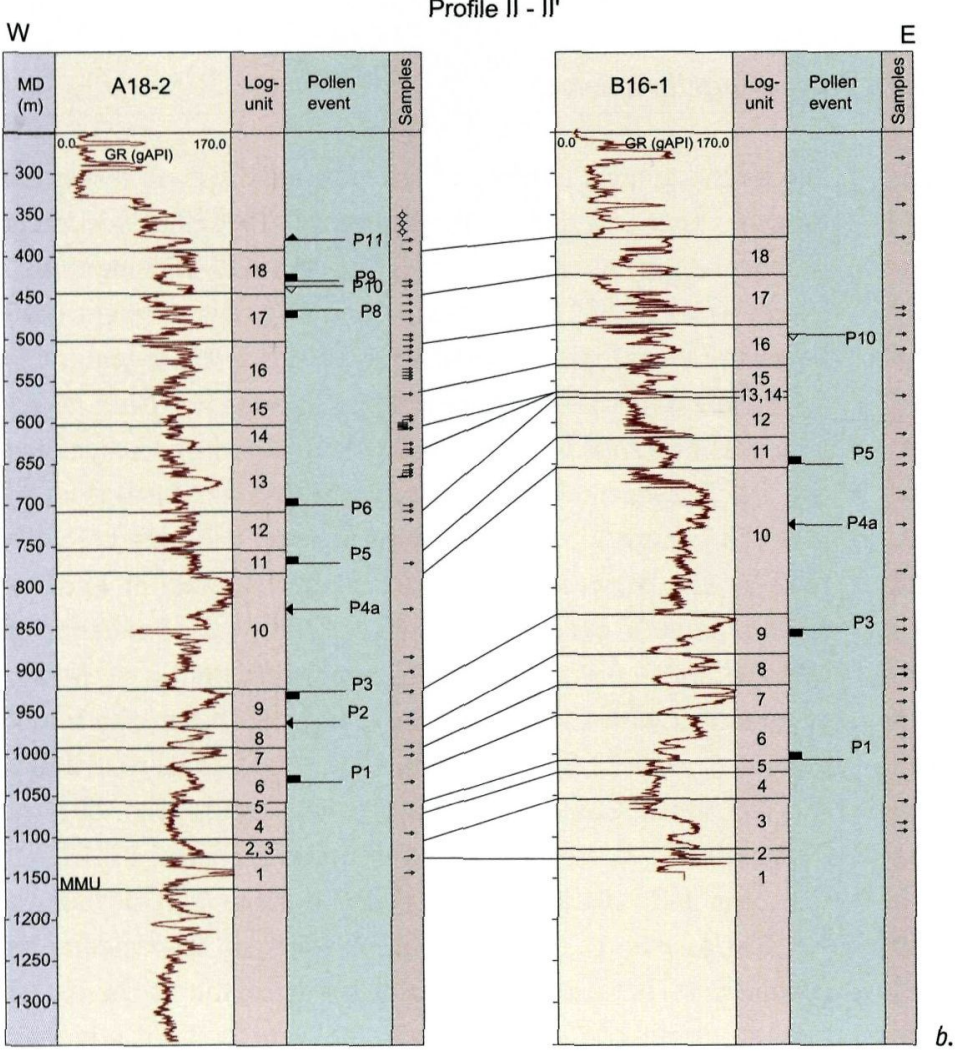

Fig. 4. a. Well-log profile (I-I') showing correlative pollen events; b. Well-log profile (II-II') showing correlative pollen events. 
Profile I - I'

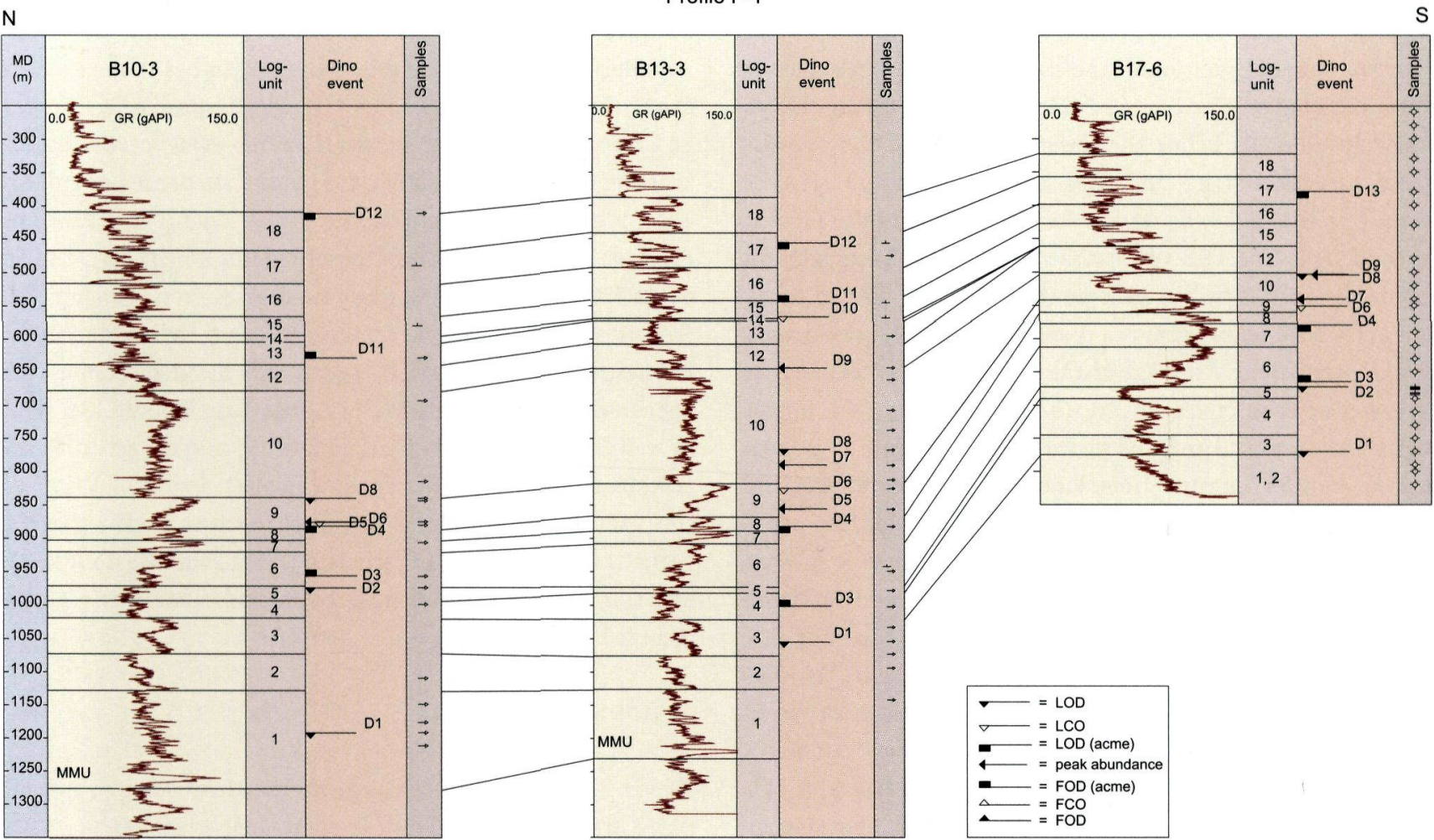

Profile III - III'

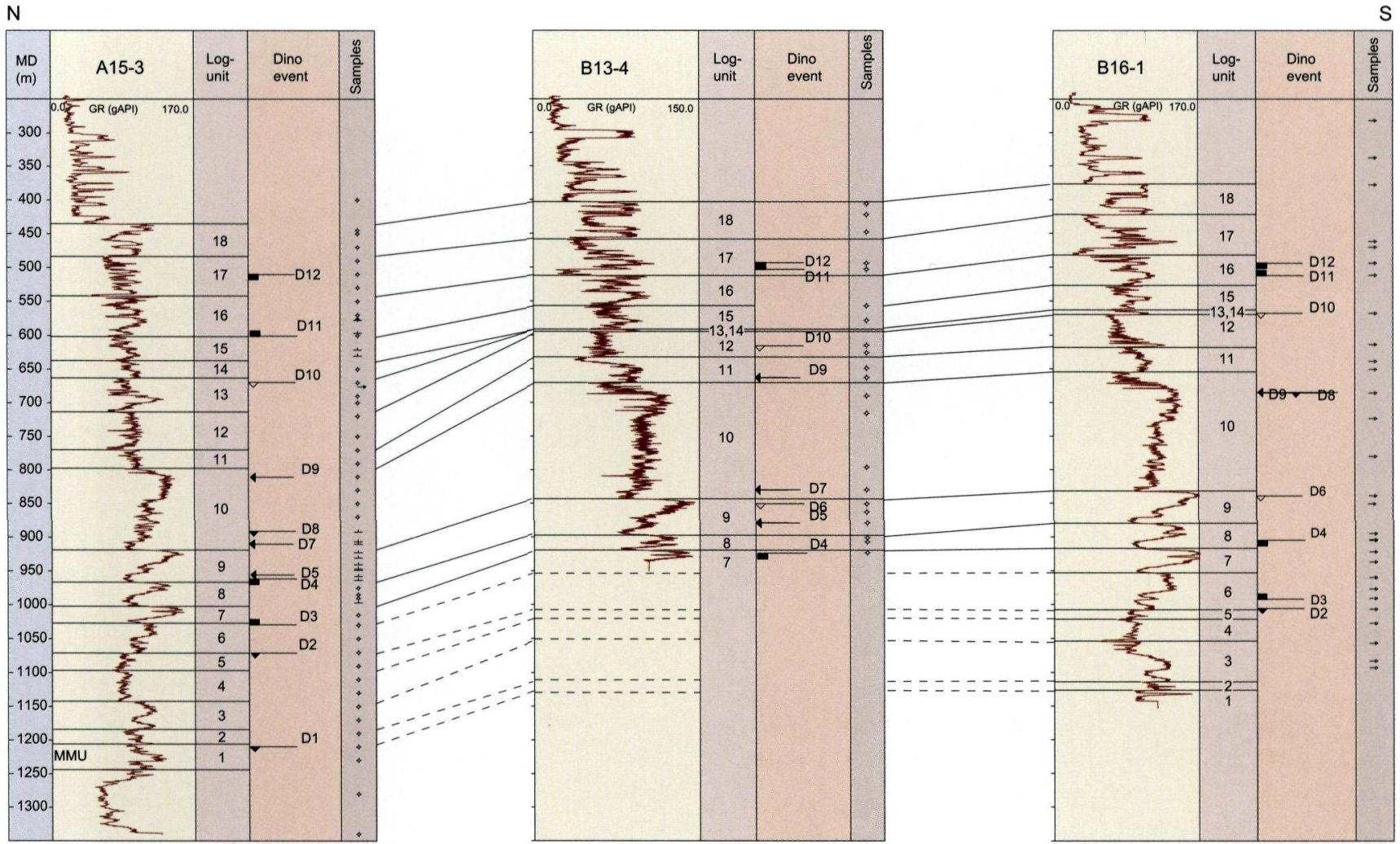

b.

Fig. 5. a. Well-log profile (I-I') showing correlative dinocyst events;. b. Well-log profile (III-III') showing correlative dinocyst events. 


\section{Foraminifera}

The stratigraphic position of the sixteen foraminifer events is given in Figure 6. The F1 event (LOD Asterigerina staeschei) is found in all wells below the lower boundary of the investigated succession (the 'Mid Miocene Unconformity'). The F2 event (top first Bulimina aculeata acme) is consistently present in logunit 1. The FOD of Elphidiella hannai (F3) appears in logunit 4 (well B17-5) or in logunit 6 for the other two wells. Logunit 4 is up to four times as thick in well B17-5, as compared to the other wells. The FCO of the species E. hannai (F3a) is recorded at base of logunit 10 in well B17-5, at the top of logunit 10 in well B10-3 and at the base of logunit 13 in well B13-3. For the interval from logunit 7 to logunit 10, the gamma-ray log correlation between well B17-5 and the other two wells is not straightforward. Since logunit 6 is well defined by the foraminifer events $\mathrm{F} 4$ (base second Bulimina aculeata acme), F5 (LCO Neogloboquadrina atlantica) and F13 (FOD of a low diversity assemblage, comparable to the FA1 zone of Doppert (1980), we assume that these events occurred synchronous (bold characters in Fig. 6). Therefore, logunits 7 and 8 seem to be condensed in well B17-5. The F14 event (LCO Melonis affinis), close to the base of logunit 9, appeared as well synchronously in all of the wells. The F7 event (LCO keeled Cassidulinida, $C$. teretis and $C$. carinata) occurred in the middle part of logunit 10 in wells B 10-3 and B13-3, whereas in well B17-5 it disappeared in logunit 9 already. The lower boundary of logunit 10 is difficult to establish in well B17-5. Because the F6 event marks a major faunal change, this event is preferred as marker for this boundary, rather than the F10a event (LCO $B$. aculeata). From the seismic profile in figure 3 and from the mentioned biostratigraphic evidence we assume that the upper part of logunit 10 is either condensed or eroded. The F10a event is present at the top of logunit 9 (B10-3), at the base (B13-3) and at the top of logunit 10 (B17-5). The F8 event (LCO Cassidulina) is recognised at the top of logunit 10 (B13-3) and in logunit 12 in the other two wells. The FOD of Haynesina orbiculare (F9) seems to be diachronous. It appeared earliest in well B10-3 (at the base logunit 13), then in well B13-3 (at the base of logunit 15) and at last in B17-5 (within logunit 17). This finding implies an introduction of this species into the North Sea from north to south. The F11 event (LCO E. hannai) is associated with logunits 16 and 17 and the apparent LOD of autochtonous foraminifers (F12) is recorded in logunit 18.

\section{Sr-isotopes}

The $\mathrm{Sr}$ isotope results measured on the three samples in well B13-3 are presented in Table 4 and at their stratigraphic depth in the composite record in Figure 7 . The ${ }^{87 / 86} \mathrm{Sr}$ values increase upward indicating ages of $0.95,1.1$ and $1.4 \mathrm{Ma}$ at face value of the seawater curve presented in Figure 9.

N

Profile I - I'

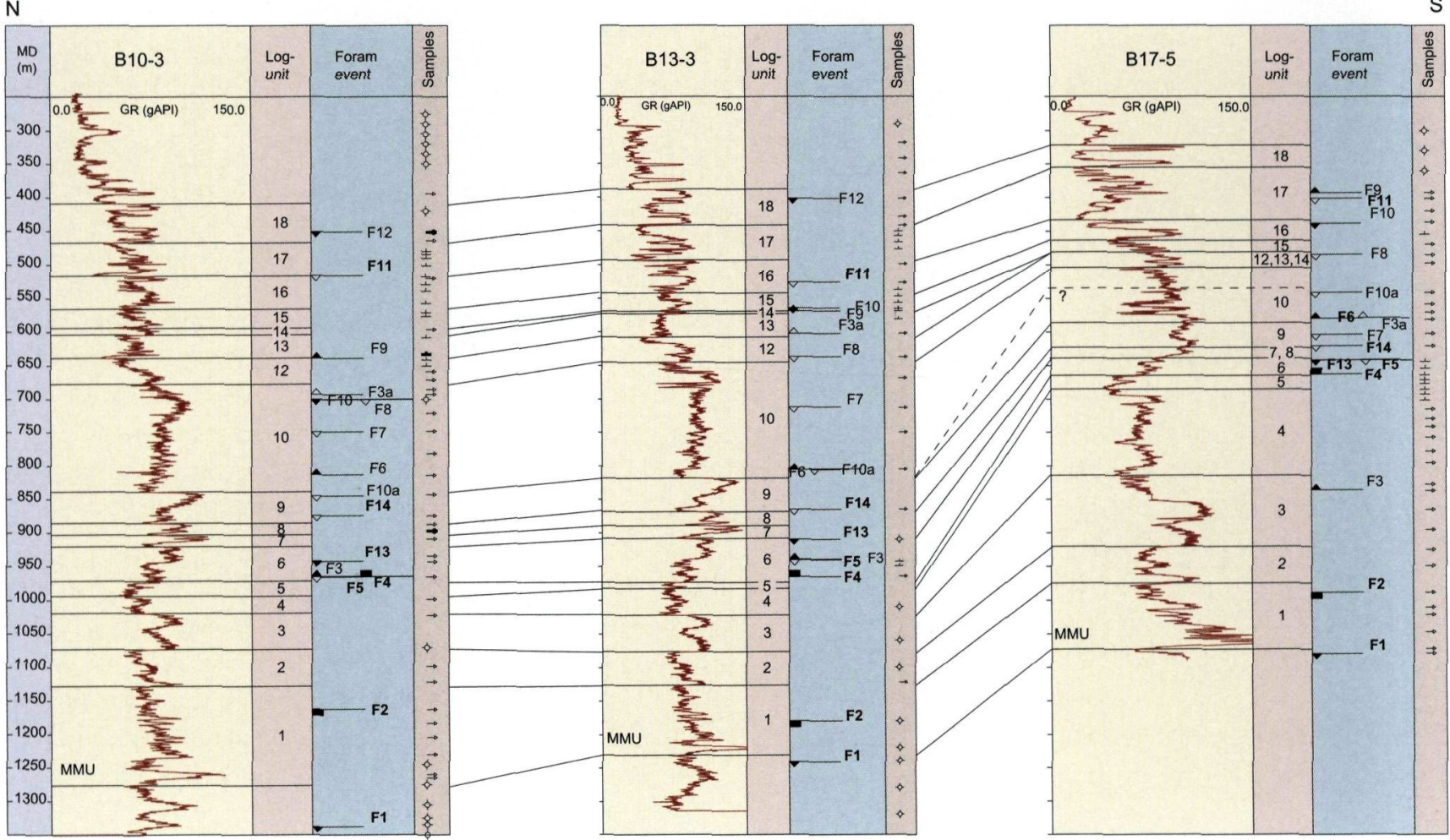

Fig. 6. Well-log profile (I-I') showing correlative foraminifer events. The bold characters indicate synchronous events. 
Table 4. Results of the Sr-isotope measurements on samples from borehole B13-3.

\begin{tabular}{llllll}
\hline Sample & $\begin{array}{l}{ }^{87 / 86} \mathrm{Sr} \\
\text { measured }\end{array}$ & 2S error & ${ }^{84 / 86} \mathrm{Sr}$ & $2 \mathrm{~S}$ error & $\begin{array}{l}{ }^{87 / 86} \mathrm{Sr} \\
\text { corrected }\end{array}$ \\
\hline $451.20-1$ & 0.709133 & 0.000010 & 0.056495 & 0.000006 & 0.709125 \\
$630.53-2$ & 0.709121 & 0.000011 & 0.056489 & 0.000006 & 0.709113 \\
$896.80-3$ & 0.709104 & 0.000009 & 0.056488 & 0.000005 & 0.709096 \\
Sr St. & 0.710248 & 0.000008 & 0.056492 & 0.000004 & 0.999989 \\
& & & & & (corr. factor) \\
Sr 987 & 0.710240 & & & & \\
\hline
\end{tabular}

\section{Discussion}

\section{Regional stratigraphical stages}

On basis of the paleoenvironmental and paleoclimatological interpretations of Kuhlmann (2004) the biostratigraphic events were taken for the interpretation in terms of existing stratigraphical stages and zones for the North Sea region. The pollen data are discussed with reference to the Dutch stages introduced by Zagwijn $(1963,1985)$, the dinocyst data to the British stages as defined by West (1961) and Beck et al. (1972) and the foraminifer data to the benthic zones of King (1983, 1989) and Doppert (1980) (compare Figs 2 and 7). These stratigraphic stages are furthermore presented in relation the global chronology for this interval.

\section{Pollen}

The marine character of the sediments and the different catchment area of the investigated North Sea succession make a direct comparison to the Dutch stages, as described by the pollen data of Zagwijn (1960 and 1963), difficult. All available data has been internally consistently interpreted and used for this correlation but some parts remain tentative. In the lower part of the succession, only few data are available but the transition from the relatively warm Brunssumian and Reuverian to the cold Pretiglian can be recognised with high confidence at the P1 event (Fig. 7). Until the top of logunit 9 the succession can be attributed to the Pretiglian. Although this period has been assigned to cold conditions (Zagwijn, 1985), the Picea acme (P2) indicates temporarily warmer conditions. This incident of warm climate is interpreted to be a short period within the Pretiglian. At the upper part of logunit 9, the assemblages are poor in pollen and invariably display a peak abundance of the fresh-water alga Pediastrum which indicates the influence of freshwater runoff occurring during cold conditions. Our findings suggest that very cold climatic conditions remained until the upper part of logunit 9, which is confirmed by the dinocyst and foraminiferal data. Despite the absence of Fagus, which is one characteristic for the
Tiglian A (Zagwijn, 1963), the second Picea acme (P4), interpreted as another short-lived warm event, has been accredited to the Tiglian A, the next warm stage after the Pretiglian. In the investigated succession the Picea acme is succeeded by abundant reworking, which in turn is succeeded by the occurrence of the herb Artemisia and Pediastrum (P4a) in the upper part of logunit 10. This distribution pattern correlates well with the characteristics described by Westerhoff et al. (1998) from the type area of the Tiglian A stage. From bottom to top, they observed a small interval with a Fagus peak and otherwise Alnus and Picea present, which they interpreted to be Tiglian A. This interval is followed by a section that is dominated by reworking and that comprises Ericales and Artemisia, which was interpreted as Tiglian B. Based on this description, we assign the basal part of logunit 10 to be Tiglian A, and the following part of logunit 10, until just below D9, is assigned to the Tiglian B. The cold conditions prevailing during this interval support furthermore indirectly the Tiglian B stage. Logunits 11 to 18 are difficult to interpret in terms of climate-based stratigraphy based on pollen because of the increasing effects of facies changes due to the proximity of the delta system. Logunits 11 to 17 are generally dominated by Ericales, Osmunda and Dryopteris. Elevated abundance of Picea is recorded in logunit 13 and 15 and peaks of reworking occur in the thin GR peak interval of logunit 13 and at the transition from logunit 16 to 17 . However, because of the first occurrence of the marker species Azolla tegeliensis (P7) in logunit 14, this interval up to logunit 17 (P8) is correlated with the Tiglian TC1 to TC4b substages. The Pinus-dominated assemblages including abundant Pediastrum is interpreted to present the cold Tiglian TC4C sub-stage in logunit 18. The FOD of Azolla filiculoides (P11) at the top of logunit 18 marks the beginning of the Tiglian $\mathrm{C} 5$ stage.

\section{Dinoflagellate cysts}

The dinocyst record has been correlated to the British stratigraphic stages based on the dinocyst events as compiled by Head (1998a). Below the D2 event, the investigated succession is relatively condensed (Fig. 7), and only few dinocyst data are available. Nevertheless, a provisional correlation can be established between the pre-D1 interval and the Gedgravian and between log unit 4 and 5 (D1 to D2) and the Waltonian. The Gedgravian is characterised by relatively deep marine dinocyst assemblages in combination with the D1 marker taxon Melitasphaeridium choanophorum (Head, 1997), which compares well with the pre-D1 record. The Waltonian is characterised by an equatorial to temperate dinocyst assemblage (e.g. Tectatodinium pellitum, Lingulodinium machaerophorum but also Bitectatodinium tepikiense) in combination with the D2 marker taxon Barssidinium spp. (Head, 1998b), suggesting correlation to log units 4 and 5. Furthermore, the planktonic foraminiferal species Neogloboquadrina atlantica and the benthic 


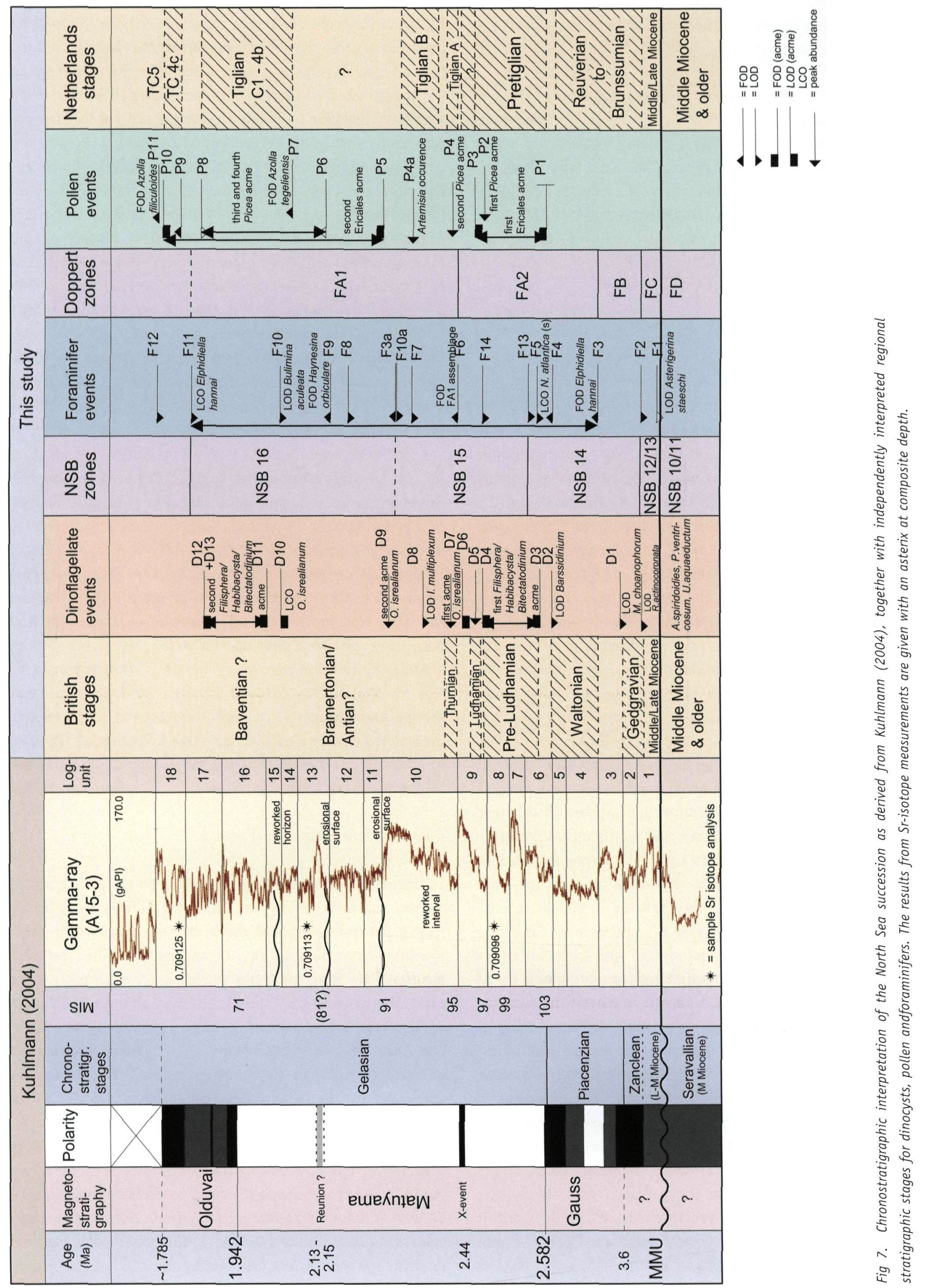


species Elphidiella hannai are consistently present in both our record as in the Waltonian of the Red Crag Formation of the British onshore succession (Gibbard et al., 1991; Funnel, 1995). The Pre-Ludhamian from the Ormesby borehole is characterised by dominance of the Filisphaera/Habibacysta group, in combination with the presence of Impagidinium multiplexum (Harland et al., 1991; Head, 1998a), suggesting a correlation of this stage to logunits 6 to 9 (D3 to D4). In the Ludham Royal Society Borehole, the succeeding Ludhamian stage yields rich dinocyst assemblages that display open marine conditions with both equatorial-temperate and sub-polar influence (Head, 1996). The distinct acme of Impagidinium multiplexum is a unique feature for this stage (Head, 1998a), which allowes correlation to the D5 event from the lower to middle part of logunit 9. The dinocyst assemblages from the Thurnian of the Ludham Royal Society Borehole are dominated by $90 \%$ Operculodinium israelianum (Head, 1996). Consequently, the basal part of logunit 10 , corresponding with the D7 event, is attributed to the Thurnian. The biological proxies from the basal part of logunit 10 (Kuhlmann, 2004), point to strong freshwater influx into the basin (D7 and Elphidium excavatum acme), in combination with a relatively warm climate (P4). Consequently, this correlation implies an equatorial to temperate sea-surface temperature (SST) for the Thurnian, a stage which is generally referred to as cold on the basis of its pollen content (West, 1961; Head, 1998a). The remaining Late Pliocene or Early Pleistocene British stages, the Antian, Bramertonian, Baventian and Pre-Pastonian, do not display uniform characteristics in the dinocyst assemblages. In general, these stages are dominated by either Operculodinium israelianum, the Filisphaera/Habibacysta group, Spiniferites spp. or a combination of these types (Harland et al., 1991; Head, 1994; Head, 1996; Zalasiewicz et al., 1991). It is therefore difficult to correlate our data to any of these stages, although the continuous presence of Amiculosphaera umbracula in the aforementioned British stages suggests a broad correlation to the interval between D7 and D13.

\section{Foraminifera}

The interpretation of the foraminiferal data is made with reference to the benthic foraminiferal zonations of Doppert (1980) and King $(1983,1989)$. On the one hand the zonation by Doppert (1980), mainly based on investigation of presentday onshore regions (Fig. 1), has always been related to the Dutch pollen zonation. The NSB (North Sea Benthic) zones by King $(1983,1989)$ on the other hand have been used in the North Sea offshore area. The latter zones can therefore be discussed directly in relation with three boreholes from the Danish offshore sector (Laursen, 1995; Konradi, 1996), which are closely located to our boreholes (Fig. 1).

In the investigated succession the F1 event (LOD A. staeschei) marks the NSB 11 zone as well as the FD zone. The NSB 12 and NSB 13 zone and the FC zones are interpreted for the interval up to the F2 event (Top first $B$. aculeata acme). These zonations are not well constrained in this part of the succession since this interval is highly condensed and none of the marker species for the NSB zones (Uvigerina sp. cf. hemmooriensis, Uvigerina pygmaea and Uvigerina venusta) could be detected. Nevertheless, this interval is characterised by various Uvigerina species. The FB zone is interpreted up to the F3 event (FOD $E$. hannai) when $E$. hannai started to occur which is then characteristic for the following FA zone. Furthermore, the species Loxostomum lammersi occurring up to that level constrain the interpretation of the FB zone. The NSB 14 zone is very well recognisable by the LOD of the marker species Monspeliensina pseudotepida (F13) that is consistently present until logunit 6 . The NSB 14 zone, covering logunits 2 to 6 , coincides with the FB and FA2 zone and is characterised by abundant Cassidulina laevigata and Bulimina aculeata. The following NSB 15 zone is not well defined in the investigated sediments because the marker species Cibicides grossus is missing. However, we place this zone between the foraminiferal events F13 and F10a (logunits 6 to 10), because the species Melonis affinis is still found in these units and the assemblage consists of diverse Cassidulina fauna (i.e. C. teretis, C. laevigata, C. carinata). Such an assemblage is well comparable with the one described by Laursen (1995) in the Danish off-shore (KIM-1 well), although this zone is absent, condensed or eroded, in two of their three investigated wells (Laursen, 1995; Konradi, 1996). The NSB 15 zone comprises the boundary of the FA2 to FA1 zone of the Netherlands foraminiferal zonation. This is consistent with the observations by Laursen (1995) who found the same decrease in diversity within this zone as seen in our record. The lower boundary of the FA1 zone is placed at the level when a low diversity assemblage (F6) consisting only of two or three species (Cassidulina spp., E. excavatum and in the upper part $E$. hannai) is introduced. The NSB 16 zone is assigned to the upper part of the succession, logunits 10 to 17, between the F3a event (FCO E. hannai) and the F11 event (LCO E. hannai).

\section{Integrated regional stratigraphy}

\section{Regional stratigraphic stages}

In this paragraph the newly established chronology for the North Sea succession (Kuhlmann, 2004) will be discussed in relation to the regional stratigraphic stages. Since neither the exact ages for most of the regional Pliocene and Pleistocene stratigraphical stages nor their duration are known an attempt has been made to relate these stages to the absolute chronology given by the Geomagnetic Polarity Time Scale (GPTS). Furthermore, the correlations of the stages made by Gibbard et al. (1991), Doppert (1980) and King (1983, 1989) will be compared to our interpretations in the previous paragraph (compare Figs 2 and 7). 
Our data suggest that the British Gedgravian and Waltonian stages are equivalent with the Brunssumian and Reuverian period. Despite the fact that the North Sea succession record is condensed for this interval, it is comparable with the correlation that has been also proposed by Gibbard et al. (1991). These stages cover the international Zanclean and Piacenzian stages and include the paleomagnetic Gauss chron (Fig. 7). The following Dutch Pretiglian and British Pre-Ludhamian stages are correlated with each other and have always been coupled to the onset of northern Hemisphere glaciation at approximately 2.6 Ma (Zagwijn, 1985). This climatic change is well recognised within the investigated succession coinciding with the GaussMatuyama boundary at 2.582 Ma. Funnell (1995) and Van den Berg \& Van Hoof (2001) assigned the Pretiglian tentatively to the period including marine isotope stages 100, 98 and 96, representing the first major cold events in the Northern hemisphere. From our data set a direct correlation between the Pretiglian and the isotope stages 100, 98 and 96 can be made (for more details reference is made to Kuhlmann, 2004).

From our marine record we can state that the periods assigned to the British Ludhamian and Thurnian represent warm intervals within an overall cold period. The Ludhamian is well constrained by the unique acme occurrence of $I$. multiplexum (D5), while the Thurnian is recognised by the acme occurrence of 0 . israelianum (D7) in our record. Acme occurrences of this species are widespread in the North Sea Basin and have been reported from the British onshore localities Ludham borehole (Head, 1996; 1998a), Ormesby borehole (Harland et al., 1991) and Chillesford Church Pit (Zalasiewicz et al., 1991), but also from the southern North Sea (middle Westkapelle Ground Formation, see Cameron et al., 1984) and from the Dutch onshore borehole Noordwijk (unpublished data). The sediments of these stages found in the nearshore areas of Britain (Fig. 1a) were probably deposited during sea-level highstands at times when marine sedimentation prevailed at these localities. This would manifest the hypothesis that the British onshore successions represent a fragmentary record covering only parts of the more continuous record found in the offshore succession. We propose that the Ludhamian and Thurnian stages represent short periods of deposition and are not continuing successional stages. The same must be valid for the nearshore setting of the Dutch onshore records. In our record, a warm period (as indicated by the first Picea acme, P2) has been found within the Pretiglian stage, which has been shown to be comparable to the Ludhamian. The Tiglian A, recognised at the second Picea peak (P4), is equivalent with the Thurnian in our record and has been interpreted to represent a warm period on top of the Pretiglian (Fig. 7). Gibbard et al. (1991) noted that an exact correlation of the Thurnian to the Tiglian sub-stages was not possible yet (Fig. 2). In contrast to Head (1998) who correlated the Thurnian to the Tiglian B by dinoflagellate evidence, our data suggest that the Thurnian is correlative to the Tiglian A, both representing short warm periods.
The second peak occurrence of 0 . israelianum (D9) probably mark another widespread dinocyst event that might have reached as far as the middle of the North Atlantic, where an isolated peak occurrence of 0 . israelianum was recorded in MIS 91 of DSDP hole 607/607A (Versteegh, 1997). Further correlation of our record with the following British and Dutch pollen- and dinocyst stages is not unambiguously possible, mainly because sedimentation became more discontinuous for the upper part of the succession.

The benthic foraminiferal zones NSB $10 / 11$ can be correlated with the FD zone and the NSB 12/13 zone with the FC zone, which is in good agreement with the correlation by King (1983). The FB zone makes only a part of the NSB 14 zone in the North Sea succession while it is assigned to the whole NSB 14 zone by King (1983). A correlation of the FB zone to the Brunssumian as well as the Gedgravian as seen in our dataset is also suggested by the compilation in figure 2 . The upper part of the NSB 14 correlates to the FB and the lower part of the FA2 zone in the investigated succession while the NSB 15 zone correlates in our case to the upper part of the FA2 zone. King (1983) assigned the whole NSB15 zone to the FA2 zone. After our interpretation the FA2 zone comprises the Waltonian and Pre-Ludhemian as well as the Reuverian and Pretiglian. According to Figure 2, the Pre-Ludhemian/ Pretiglian stages were previously related to the NSB 16 and the FA1 zone. The species Elphidium oregonense that marks the interval between the FA2 and FA1 zone has not been found in our record. In the investigated succession the FA1 zone comprises the upper part of the NSB 15 and the NSB 16 zone as well as the Tiglian A, B and the Tiglian C1-4b and the Thurnian, Bramertonian/Antian and the Baventian. The NSB 17 zone comprises the Tiglian C4C and the TC5 stage (Fig. 7).

Based on the combined dataset of Kuhlmann (2004) and this study, it can furthermore stated that the base of the Olduvai subchron, which is connected to the warm MIS 71 (Lourens et al., 1996) can now be assigned to the TC1-4b substage. Until now, this boundary has only been indirectly correlated to the TC1-4b stage (Funnel, 1996; Zagwijn, 1998) since the available paleomagnetic data from the southern North Sea Basin has been insufficient for this interval (Fig. 2). Our data confirm the hypothesis by Funnel (1996) and Van den Berg \& Van Hoof (2001) who correlated the cold TC4C substage to MIS 70 or 68 within the Olduvai chron.

\section{Implications from the foraminiferal (NSB) zones for the age assessment of the sedimentary units}

In the following the correlative sequences and logunits of well A18-1 (Fig. 1), used in the study by Sørensen et al. (1997), and the logunits of the well B13-3, used in this study, are discussed with respect to the chronology based on the NSB zones (Fig. 8). As shown in the correlation diagrams of the previous section, the boundaries of the logunits are assumed to occur synchronously 


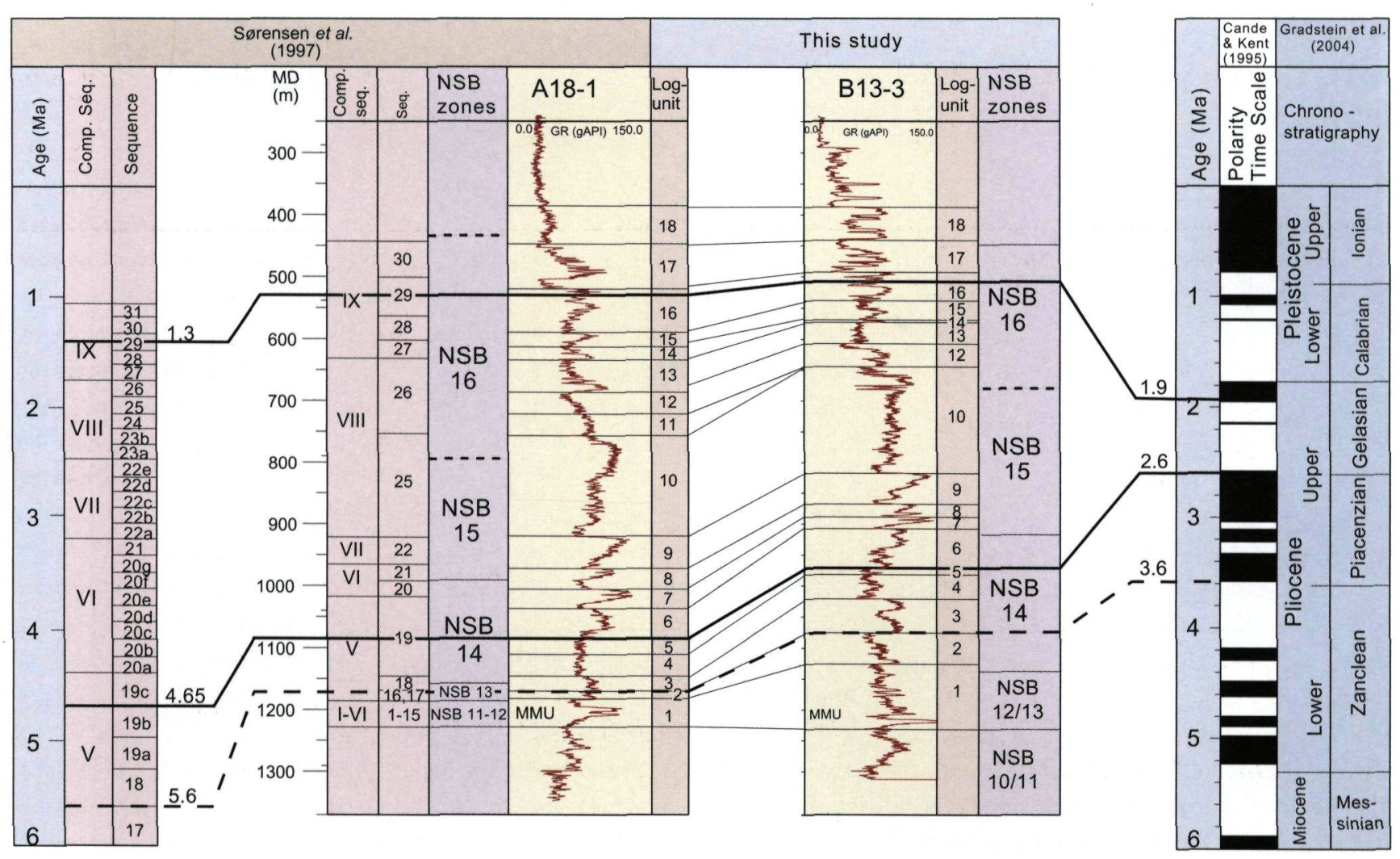

Fig. 8. Correlation of the gamma ray logs of wells A18-2 and B13-3 with the interpreted NSB zones for the logunits/sequences from this study those by Sørensen et al. (1997).

within the studied area and display consequently equal timelines. Therefore, the boundaries of the NSB zones should be correlative within the two boreholes.

Comparison of the NSB zone boundaries with the correlative sequences and logunits (Fig. 8) shows that our logunit 1 and logunits 1 to 3, respectively sequences 1 to 18 of Sørensen et al. (1997) cover the zones from NSB 10 to NSB 13. The NSB 14 zone comprises logunits 4 to 7 , respectively sequences 19 and 20 in the study of Sørensen, while this zone comprises logunits 2 to 6 in our study. This implies that the NSB 14 zone occurs slightly earlier for the wells in our study. The following boundary between NSB 15 and NSB 16 and the top of NSB 16 occur within the same logunits, i.e. within logunit 10 and between logunit 17 and 18. Generally speaking, the NSB zones match quite well between the wells but it is questionable if the NSB zones are precise enough for an absolute age assessment of the sediments. While Sørensen et al. (1997) derived absolute ages purely from biostratigraphy, the ages in this study were additionally constrained by independent paleomagnetic data (Kuhlmann, 2004). From comparison of these ages (Fig. 8) it is obvious that the absolute ages used by Sørensen et al. (1997) differ between 2 Myrs and 0.6 Myrs to these obtained in our study. It seems that the benthic foraminiferal zonations and, as shown in the previous paragraph, that the regional stratigraphical stages (based on data from onshore locations) are not accurate enough for detailed age determination in more complete successions as the offshore North Sea sediments.

\section{Sr isotope chronology}

In addition to paleomagnetic measurements, strontium isotope analysis is another method that can be used to determine absolute ages for Pliocene sediments. This method was applied on three samples from the North Sea succession. The analysed samples are plotted with their stratigraphic depth, related to the gamma-ray log, in Figure 7. In Figure 9, the results obtained by our study are presented in relation to the standard seawater curve by Farrell et al. (1995). This graph shows the average variation of the $87 \mathrm{Sr} / 86 \mathrm{Sr}$ ratio in seawater of the Indian Ocean. The Best-Fit-curve as given by McArthur et al. (2001) corresponds to the upper confidence interval for the time interval presented in Figure 9. The resulting ages from this standard seawater curve are approximately $0.95,1.1$ and $1.4 \mathrm{Ma}$ for the three samples measured. Surprisingly, the approximate age of the samples which is given by the paleomagnetic boundaries, i.e. 1.8 Ma, 2.14 Ma and 2.45 Ma, show a consistent offset of $1 \mathrm{Myr}$ in age. Considering the paleomagnetic timescale, this would imply that the uppermost normal polarity would then be related the Jaramillo subchron and the lower one to the Olduvai subchron. However, this conclusion seems, with regard to the previous discussed biostratigraphic data (Kuhlmann, 2004 and this study), not very likely because the paleomagnetic calibrated last occurrence datums of foraminifer species Neogloboquadrina atlantica and of the dinocysts Barssidinium spp. and Amiculosphaera umbracula point to an 


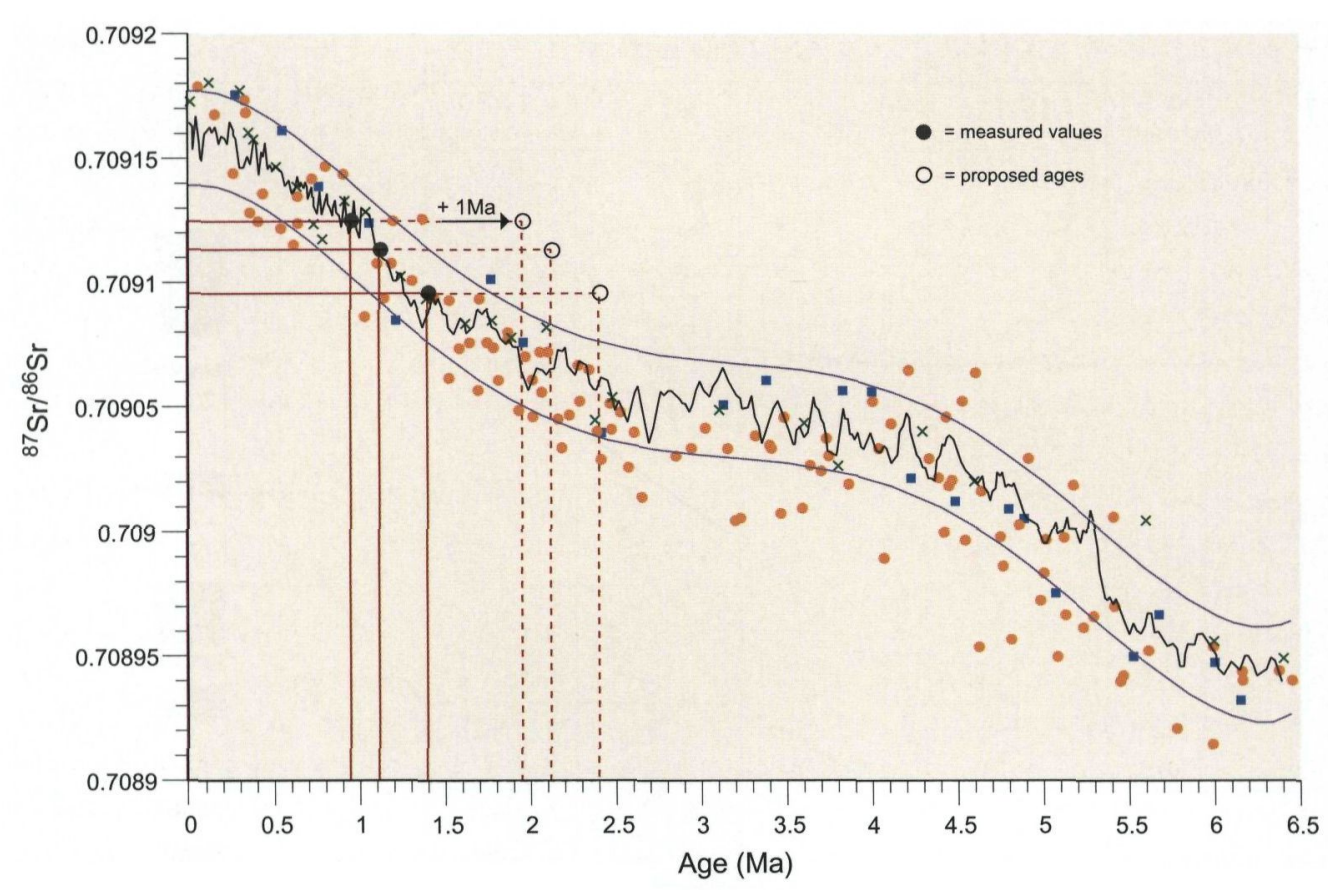

Fig. 9. Curve showing strontium isotope evolution of seawater from 6.5 Ma to present after Farrel et al. (1995) with the integrated three measurements of this study (filled dots). After the presented chronology the ages appear to be consistently 1 Ma too young as indicated by open dots. Thus ${ }^{87} \mathrm{Sr} /{ }^{86} \mathrm{Sr}$ values are higher in the measured samples than expected from the chronology as given by Kuhlmann (2004). age between the Olduvai subchron and the Gauss chron. Therefore, we suggest that the normal polarities represent respectively the Olduvai subchron and the Gauss-Matuyama boundary (Fig. 7). One explanation for the consistently higher ${ }^{87} \mathrm{Sr} /{ }^{86} \mathrm{Sr}$ values can be that the strong continental freshwater input in the sedimentary system increases the strontium ratio. Palmer and Edmond (1989) showed that the mean ${ }^{87} \mathrm{Sr} /{ }^{86} \mathrm{Sr}$ ratio for global river runoff $(0.7119)$ is higher than that of the average seawater inventory (0.7092). Probably, the watermasses of the Pliocene North Sea display not the average ${ }^{87} \mathrm{Sr} /{ }^{86} \mathrm{Sr}$ ratio for open marine seawater as given by the standard seawater curve as also the paleoenvironmental interpretations of (Kuhlmann, 2004) underline the high fluvial freshwater input into the North Sea Basin. This should be the reason why the $\mathrm{Sr}$ isotope method provides too young ages for the Plio- Pleistocene time interval and it may be questioned if this method can be used for independent dating of sediments in an environmental setting such as the Pliocene North Sea system.

\section{Conclusions}

- In previous studies (Kuhlmann, 2004) an integrated chronology, based on biostratigraphy and paleomagnetic reversals, has been constructed for the Neogene North Sea succession. The present study shows the detailed correlation between the investigated boreholes using gamma-ray logs and the biostratigraphic events of Kuhlmann (2004). It constrains the consistency of the dataset and validates the assumption that logstratigraphic boundaries represent time equivalent horizons. The biostratigraphic data has subsequently been interpreted in terms of the regional stratigraphic stages which are often used as standard zonations in the North Sea region. A new correlation of the regional stages and connection to the global (standard) chronostratigraphy has been elaborated for the marine succession in the Dutch offshore sector in the southern North Sea.

- The British Gedgravian and Waltonian stages, the Dutch Reuverian to Brunssumian and foraminiferal zones NSB 14, FB and the lower part of the FA2 zone fall within the Zanclean and Piacenzian chronostratigraphic stages. The boundaries to the Pre-Ludhamian, to the Pretiglian and to the NSB 14 zone are located close to the paleomagnetic Gauss-Matuyama boundary. The Pre-Ludhamian, Ludhamian, Thurnian and the Pretiglian, Tiglian A and Tiglian B stages presumably cover the marine isotope stages 103 to 95 . The Ludhamian, Thurnian and the Tiglian A were presumably short lasting, warm, periods during which sea level highstand facilitated sedimentary deposition at the marginal areas of the North Sea Basin. The lower boundary of the paleomagnetic Olduvai subchron is situated in the Tiglian C1-4b stage while the TC4C stage is found within the Olduvai subchron. Foraminiferal NSB15 and NSB 16 zone as well as the upper part of the FA2 and FA1 zone fall within the Gelasian and cover the Matuyama chron as well as the lower part of the Olduvai subchron.

- Comparison of the correlation of the interpreted stratigraphic zones with correlation of former studies (Gibbard et al., 1991; King, 1989) show similarities but also differences between our and the former correlations. Besides some slight discrepancies, there is a relatively good agreement between the interpretations of the foraminiferal zones of Doppert with the Netherlands regional stages in the North Sea succession as proposed by Doppert (1980) and Zagwijn (1985). The two foraminiferal zonations are comparable with the correlation given by King (1983). The regional British 
and Netherlands stages found in the lower part of the investigated succession fit well with proposed correlations by Gibbard et al. (1991). In the middle part, however, a distinct offset has been observed for the stages: the Ludhamian is interpreted as a short, warm period within the Pretiglian stage and the Thurnian is equivalent to the Tiglian A.

- Logstratigraphical control of the units allowed the connection to regional sequence stratigraphic interpretations. Compared to these studies, the former ages for the sediments differ between $2 \mathrm{Ma}$ and 0.6 Ma. Therefore, it is concluded that foraminiferal zonations are useful for an approximate relative age determination in the North Sea region but are still not well calibrated to the GPTS and to global chronology. Furthermore, it has been shown that the onshore sediments represent discontinuous records that were deposited during periods of relative sea level high stands and include periods of non-deposition.

- An attempt has been made with application of the strontium isotope method to obtain more independently derived absolute ages points. It appeared that the sedimentary succession is in stratigraphical order but that the ages were approximately 1 Myr younger than expected from the combined results from bio- and magnetostratigraphy. In this context an increase in the ${ }^{87} \mathrm{Sr} /{ }^{86} \mathrm{Sr}$ ratio can be explained by the high continental freshwater run-off into the North Sea Basin.

\section{Acknowledgements}

This research is part of the PhD project of G.K. The funding of this project by Wintershall Noordzee B.V. and its partners Marathon Oil Company, Dana Petroleum and Energie Beheer Nederland (EBN) is gratefully acknowledged. We thank Wintershall Noordzee B.V. and NAM (Nederlandse Aardolie Maatschappij) for providing the offshore samples to this study and for the permission to publish the results. Measurements of the $\mathrm{Sr}$ isotopes has been made possible through the MarieCurie-Trainings-Site (SNEHILO) at the University of Bergen, Norway. This work has been carried out at Utrecht University and TNO Built Enviroment and Geosciences - Geological Survey of the Netherlands.

\section{References}

Aguirre, E. \& Pasini, G., 1985. The Pliocene - Pleistocene boundary. Episodes 8 (2): 116-120.

Beck, R.B, Funnell, B.M. \& Lord, A.R., 1972. Correlation of the Lower Pleistocene Crag at depth in Suffolk. Geological Magazine 109: 137-139.

Berggren, W.A., Hilgen, F.J., Langereis, C.G., Kent, D.V., Obradovitch, J.D., Raffi, I., Raymo, M. \& Shackelton, N.J., 1995a. Late Neogene chronology: New perspectives in high-resolution stratigraphy. Bulletin of the Geolical Society of America 107 (11): 1272-1287.
Berggren, W.A., Kent, D.V., Swisher, C.C. \& Aubry, M-P., 1995b. A revised Cenozoic geochronology and chronostratigraphy. Geochronology time scales and global stratigraphic correlation, Society for Sedimentary Geology (SEPM) special publication 54: 129-212.

Bijlsma, S., 1981. Fluvial sedimentation from the Fennoscandian area into the Nortwest European Basin during the Late Cenozoic. Geologie en Mijnbouw 60: 337-345.

Boenigk, W., Koci, A. \& Brunnacker, K., 1979. Magnetostratigraphie im Pliozaen der Niederrheinischen Bucht. Neues Jahrbuch fuer Geologie und Palaeontologie 9: 513-528.

Cameron, T.D.J., Bonny, A.P., Gregory, D.M. \& Harland, R., 1984. Lower Pleistocene dinoflagellate cyst, forminiferal and pollen assemblages in four boreholes in the Southern North Sea. Geological Magazine 121 (2): 85-97.

Cande, S.C. \& Kent, D.V., 1995. Revised calibration of the geomagnetic polarity timescale for the Late Cretaceous and Cenozoic. Journal of Geophysical Research 100 (B4): 6093-6095.

De Jong, J., 1988. Climatic variability during the past three million years, as indicated by vegetational evolution in northwest Europe and with emphasis on data from the Netherlands. Philosophical Transactions of the Royal Society of London, B318: 603-617.

De Vernal, A., Londeix, L., Mudie, P.J., Harland, R., Morzadec-Kerfourn, M.T., Turon, J.L. \& Wrenn, J.H., 1992. Quaternary organic-walled dinoflagellate cysts of the North Atlantic 0cean and adjacent seas: eco-stratigraphy and biostratigraphy. In: Head, M.J. \& Wrenn, J.H. (eds): Neogene and Quaternary Dinoflagellate Cysts and Acritarchs. American Association of Stratgraphic Palynologists Foundation (Dallas): 289-328.

Doppert, J.W.C., 1980. Lithostratigraphy and biostratigraphy of marine Neogene deposits in the Netherlands. Mededelingen Rijks Geologische Dienst 32-16: 255-311.

Eidvin, T., Riis, F. \& Rundberg, Y., 1999. Upper Cainozoic stratigraphy in the central North Sea (Ekofisk and Sleipner fields). Geologisk Tidsskrift 79: 97-128.

Farrell, J.W., Clemens, S.C. \& Gromet, L.P., 1995. Improved chronostratigraphic reference curve of late Neogene seawater ${ }^{87} \mathrm{Sr} /{ }^{86} \mathrm{Sr}$. Geology 23 (5): 403-406.

Funnel, B., 1996. Global sea-level and the (pen-)insularity of late Cenzoic Britain. In: Island Britain: a Qaternary perspective, Preece, R.C. (ed.), Special Publication of the Geological Society 96: 3-13.

Glennie, K.W., 1990. Introduction to the petroleum geology of the North Sea. Blackwell (0xford): $402 \mathrm{pp}$.

Gibbard, P.L., West, R.G., Zagwijn, W.H., Balson, P.S., Burger, A.W., Funnel, B.M., Jeffery, D.H., de Jong, J., van Kolfschoten, T., Loster, A.M., Meijer, T., Norton, P.E.P., Treece, R.C., Rose, J., Stuart, A.J., Whiteman, C.A. \& Zalasiewicz, J.A., 1991. Early and Early Middle Pleistocene Correlations in the southern North Sea Basin. Quaternary Science Reviews 10: 23-52.

Gradstein, F. \& Backström, S., 1996. Cainozoic biostratigraphy and palaeobathymetry, northern North Sea and Haltenbanken. Norsk Geologisk Tidskrift 76: 3-32.

Gradstein, F.M., Ogg, J.G., \& Smith, A.G. (eds), 2004. A Geologic Time Scale 2004. Cambridge University Press: 589 pp.

Hallam, D.F. \& Maher, B.A., 1994. A record of reversed polarity carried by the iron sulphide greigite in British early Pleistocene sediments. Earth and Planetary Science Letters 121: 71-80. 
Harland, R., 1979. Dinoflagellate biostratigraphy of Neogene and Quaternary sediments at Holes 400/400A in the Bay of Biscay (Deep Sea Drilling Project Leg 8). In: L. Montadert, D.G. Roberts et al. (eds), Initial Reports of the Deep Sea Drilling Project, 48. U.S. Government Printing Office (Washington): 531545.

Harland, R., Bonny, A.P., Hughes, M.J. \& Morigi, A.N., 1991. The lower Pleistocene stratigraphy of the Ormesby Borehole, Norfolk, England. Geological Magazine 128: 647-660.

Harland, R., 1992. Dinoflagellate cysts of the Quaternary system. In: Powell, A.J. (ed.). A stratigraphic index of dinoflagellate cysts. Chapman and Hall (London): 253-280.

Head, M.J., 1994. Morphology and paleoenvironmental significance of the Cenozoic dinoflagellata genera Habibacysta and Bitectatodinium. Micropaleontology 40: 289-321.

Head, M.J., 1996. Late Cenozoic dinoflagellates from the Royal Society Borehole at Ludham, Norfolk, Eastern England. Journal of Paleontology 70: 543-570.

Head, M.J., 1997. Thermophilic dinoflagellate assemblages from the mid Pliocene of eastern England. Journal of Paleontology 71: 165-193.

Head, M.J., 1998a. Marine environmental change in the Pliocene and early Pleistocene of eastern England: the dinoflagellate evidence reviewed. Mededelingen Nederlands Instituut voor Toegepaste Geowetenschappen TN0 60: $199-225$.

Head, M.J., 1998b. Pollen and dinoflagellates from the Red Crag at Walton-onthe-Naze, Essex: evidence for a mild climatic phase during the early Late Pliocene of eastern England. Geological Magazine 135: 803-817.

Huuse, M., 2002. Late Cenozoic palaeogeography of the estern North Sea Basin: climate vs. tectonic forcing of basin margin uplift and deltaic progradation. Bulletin of the Geological Society of Denmark 49: 145-170.

Kasse, C., 1996. Paleomagnetic dating and effects of Weichselian periglacial processes on the magnetization of early Pleistocene deposits (southern Netherlands, northern Belgium). Geologie en Mijnbouw 75: 19-31.

King, C., 1983. Cainozoic micropalaeontological biostratigraphy of the North Sea. Report Institute Geological Sciences 82: 1-40: 6 pl.

King, C., 1989. Cenozoic of the North Sea. In: Jenkins, D.G. \& Murray, J.W. (eds) Stratigraphical atlas of fossil Foraminifera. Chichester, Ellis Horwood: 418489.

Konradi, P.B., 1996. Foraminiferal biostratigraphy of the post-mid Miocene in the Danish Central Trough, North Sea. In: De Batist, M.P.J. (ed), Geology of siliclastic shelf seas. Geol. Soc.Spec. Publ. 117: 15-22.

Kuhlmann, G., 2004. High resolution stratigraphy and paleoenvironmental changes in the southern North Sea during the Neogene - An integrated study of Late Cenozoic marine deposits from the northern part of the Dutch offshore area. Ph.D. thesis, Utrecht University, Geologica Ultraiectina, Mededelingen van de Faculteit Aardwetenschappen 245: 205 pp.

Laursen, G.V., 1995. Foraminiferal analyses of Tertiary deposits in the North Sea area: Stratigraphy, palaeoecology and taxonomy. Ph.D. thesis, University of Aarhus: 267 pp.

Lourens, L.J., Hilgen, F.J., Zachariasse, W.J., Van Hoof, A.A.M., Antonarakou,

A. \& Vergnaud-Grazzini, C., 1996. Evaluation of the Pliocene to early Pleistocene astronomical time scale, Paleoceanography 11: 391-413.
Matthiessen, J. \& Brenner, W., 1996. Dinoflagellate cyst ecostratigraphy of Pliocene-Pleistocen sediments from the Yermak Plateau (Arctic Ocean, Hole 911A). In: Thiede, H., Myhre, A.M., Firth, J.V., Johnson, G.L. \& Ruddiman, W.F. (eds): Proceedings of the Ocean Drilling Program, Scientific Results 151: College Station, TX (0cean Drilling Program): 243-253.

Mauz, B., 1998. The onset of the Quaternary: A review of new findings in the Pliocene-Pleistocene chronostratigraphy. Quaternary Science Reviews 17 (4-5): 357-364.

McArthur, J.M., Howarth, R.J. \& Bailey, T.R., 2001. Strontium Isotope Stratigraphy: LOWESS Version 3: Best Fit to the Marine Sr-Isotope Curve for 0 - $509 \mathrm{Ma}$ and Accompanying Look-up Table for Deriving Numerical Age. The Journal of Geology 109: 155-170.

Mudie, P.J., 1989. Palynology and dinocyst biostratigraphy of the late Miocene to Pleistocene, Norwegian Sea ODP Leg 104, Sites 642 to 644. In: Eldholm, 0. Thiede, J., Tayler, E., et al. (eds): Proceedings of the Ocean Drilling Program College Station, Texas: $568 \mathrm{pp}$.

Oakley, K.P., 1949. The Plio-Pleistocene boundary. Proceedings of the International Geological Congress, 18th session, 1948: Section H. Geological Magazine 86: 18-21.

Palmer, M.R. \& Edmond, J.M., 1989. The strontium isotope budget of the modern ocean. Earth and Planetary Science Letters 92: 11-26.

Poulsen, N.E., Manum, S.B., Williams, G.L. \& Ellegaard, M., 1996. Tertiary dinoflagellate biostratigraphy of Sites 907, 908 and 909 in NorwegianGreenland Sea. In: Thiede, J., Myhre, A.M., Firth, J.V., Johnson, G.L. \& Ruddiman, W.F. (eds): Proceedings of the Ocean Drilling Program, Scientific Results, College Station, TX (0cean Drilling Program): 255-287.

Smelror, M., 1999. Plio-Pleistocene and redeposited dinoflagellate cysts from the western Svalbard margin (Site 986): biostratigraphy, paleoenvironment and sediment provenance. In: Raymo, M.E., Jansen, E., Blum, P. \& Herbert, T.D. (eds): Proceedings of the Ocean Drilling Program, Scientific Results, College Station, TX (0cean Drilling Program): 83-97.

Sørensen, J.C., Gregersen, U., Breiner, M. \& Michelsen, O., 1997. High-frequency sequence stratigraphy of Upper Cenozoic deposits in the central and southeastern North Sea areas. Marine and Petroleum Geology 14 (2): 99-123.

Urban, B., 1978. The interglacial of Frechen/Rheinland - a section of the Tiglian A-type. Geologie en Mijnbouw 57: 401-406.

Van Adrichem Boogaert, H.A. \& W.F.P. Kouwe (eds), 1997. Stratigraphic nomenclature of the Netherlands, revision and update by RGD and NOGEPA, Section Tertiary (Lower, Middle and Upper North Sea Groups). Mededelingen Rijks Geologische Dienst 50 (I): 1-39, 6 annexes.

Van den Berg, M.W. \& Van Hoof, A.A.M., 2001. The Maas terrace sequence at Maastricht, SE Netherlands: evidence for $200 \mathrm{~m}$ of late Neogene and Quaternary surface uplift. In: Maddy, D., Macklin, M.G. \& Woodward, J.C. (eds): River Basin Sediment Systems: Archives of Environmental Change. A.A. Balkema Publishers (Lisse): 45-86.

Van der Vlerk, I.M. \& Florschütz, F., 1950. Nederland in het ijstijdvak. Utrecht: $287 \mathrm{pp}$.

Van Montfrans, H.M., 1971. Paleomagnetic dating in the North Sea Basin. Earth and Planetary Science Letters 11: 226-235.

Van Voorthuysen, J.H., Toering, K. \& Zagwijn, W.H., 1972. The Plio-Pleistocene boundary in the North Sea Basin; revision of its position in the marine beds. Geologie en Mijnbouw 51 (6): 627-639. 
Versteegh, G.J.M., 1995. Paleoenvironmental changes in the Mediterranean and North Atlantic in relation to the onset of Northern Hemisphere glaciations - a palynological approach. Published thesis, University of Utrecht, Ponsen en Looijen (Wageningen): $134 \mathrm{pp}$.

Versteegh, G.J.M., 1997. The onset of major Northern Hemisphere glaciations and their impact on dinoflagellate cysts and acritarchs from the Singa section, Calabria (southern Italy) and DSDP Holes 607/607A (North Atlantic). Marine Micropaleontology 30: 319-343.

Vinken, R., 1988. The North West European Tertiary Basins. Results of the International Geological Correlation Programme, Project No. 124, Geologisches Jahrbuch 100: 508 pp.

Weaver, P.P.E. \& Clement, B.M., 1986. Synchronicity of Pliocene planktonic foraminiferal datums in the North Atlantic. Marine Micropalaeontology 10: 295-307.

Weaver, P.P.E., 1987. Magnetobiostratigraphy of planktonic foraminiferal datums, DSDP Leg 94, North Atlantic. In: Ruddiman, W.F., Kidd, R.B., Thomas, E., et al., Initial Reports of the DSDP, 94: Washington, 815-829.

West, R.G., 1961. Vegetational history of the Early Pleistocene of the Royal Society Borehole at ludham, Norfolk. Proceedings of the Royal Society of London, B155: 437-453.

Westerhoff, W.E., Cleveringa, P., Meijer, T., van Kolfschoten, T. \& Zagwijn, W.H., 1998. The Lower Pleistocene fluvial (clay) deposits in the Maalbeek pit near Tegelen, the Netherlands. In: Van Kolfschoten, T. \& Gibbard, P.L. (eds): The Dawn of the Quaternary, Proceedings of the SEQS-EuroMam symposium., Mededelingen NITG-TNO 60: 35-69.

Zagwijn, W.H., 1957. Vegetation, climate and time-correlations in the Early Pleistocene of Europe. Geologie en Mijnbouw 19: 233-244.

Zagwijn, W.H., 1960. Aspects of the Pliocene and Early Pleistocene vegetation of the Netherlands. Mededelingen Geologische Stichting C III-I, 5: $78 \mathrm{pp}$.

Zagwijn, W.H., 1963. Pollen-analytic investigations in the Tiglian of the Netherlands. Mededelingen Geologische Stichting 16: 49-72.

Zagwijn, W.H., 1974. The paleogeographic evolution of the Netherland during the Quarternary. Geologie en Mijnbouw 53 (6): 369-385.

Zagwijn, W.H., 1985. An outline of the Quaternary stratigraphy of the Netherlands. Geologie en Mijnbouw 64: 17-24.

Zagwijn, W.H., 1992. The beginning of the Ice Age in Europe and its major subdivisions. Quaternary Science Reviews 11: 583-591.

Zagwijn, W.H., 1998. Borders and boundaries; a century of stratigraphical research in the Tegelen-Reuver area of Limburg (the Netherlands). In: The dawn of the Quaternary; proceedings of the SEQS-EuroMam symposium 1996: Van Kolfschoten, Th. \& Gibbard, P.L. (eds): Mededelingen Nederlands Instituut voor Toegepaste Geowetenschappen TN0 60: 19-34.

Zagwijn, W.H. \& Doppert, J.W.C., 1978. Upper Cenozoic of the southern North Sea Basin: Palaeoclimatic and Palaeogeographic evolution. Geologie en Mijnbouw 57 (4): 577-588.

Zalasiewicz, J.A., Mathers, S.J., Gibbard, P.L. Peglar, S.M, Funnell, B.M., Catt, J.A., Harland, R., Long, P.E. \& Austin, T.J.F., 1991. Age and relationship of the Chillesford Clay (early Pleistocene: Suffolk, England). Philosphical Transactions of the Royal Society of London 333: 81-100.

Ziegler, P., 1990. Geological atlas of Western and Central Europe. 3rd edition, Shell International Petroleum Maatschappij B.V.: 239 pp. 